\title{
Home visit: an educational health strategy for self-care in diabetes
}

Visita domiciliária: estratégia educativa em saúde para o autocuidado em diabetes

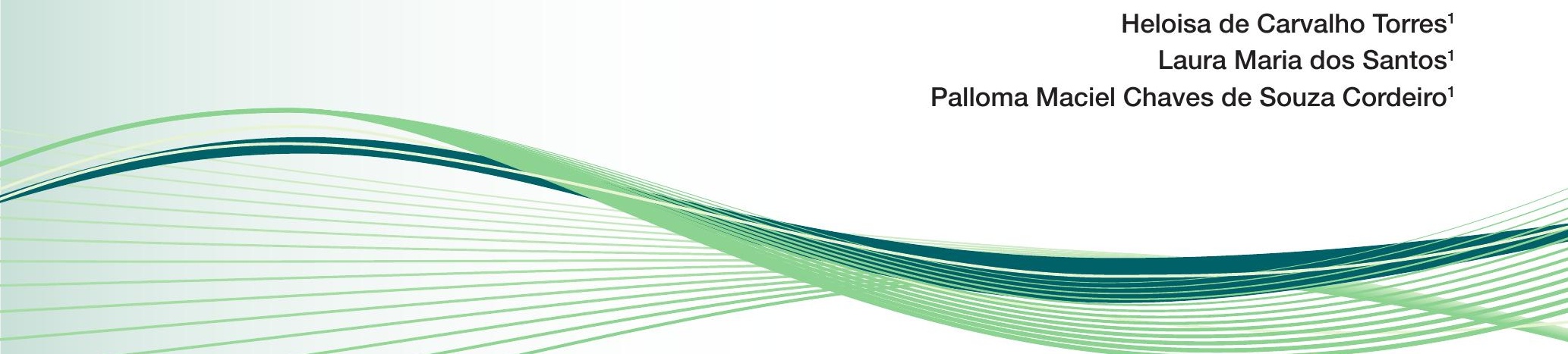

Keywords

Public health nursing; Nursing education; Nursing primary care; Diabetes mellitus type 2; Self care

\section{Descritores}

Enfermagem em saúde pública;

Educação em enfermagem;

Enfermagem de atenção primária;

Diabetes mellitus tipo 2; Autocuidado

Submitted January 16, 2014

Accepted

February 26, 2014

\section{Abstract}

Objective: To understand the home visit as an educational health care strategy to orient the self-care practices of patients with type 2 diabetes mellitus.

Methods: A qualitative study using 25 home visits to patients with diabetes mellitus, who did not attend the diabetes education program offered by the basic health care unit. Data were organized and categorized by content analysis.

Results: Four thematic categories emerged: feelings; knowledge about the disease; adherence to meal plan and physical activity; and barriers to self-care.

Conclusion: Home visit is an important strategy for health care education to orient patients with type 2 diabetes on self-care practices.

\section{Resumo}

Objetivo: Compreender a visita domiciliária como estratégia educativa em saúde a para orientar as práticas do autocuidado aos portadores de diabetes mellitus tipo 2.

Métodos: Pesquisa qualitativa utilizando 25 visitas domiciliárias a portadores de diabetes mellitus que não compareceram ao programa educativo em diabetes da unidade básica de saúde. Os dados foram organizados, categorizados mediante a análise de conteúdo.

Resultados: Emergiram quatro categorias temáticas: Sentimentos; Conhecimento sobre a doença; Seguimento do plano alimentar e atividade física; e Barreiras para o autocuidado

Conclusão: A visita domiciliária é uma importante estratégia para a educação em saúde para orientar as práticas do autocuidado aos portadores de diabetes mellitus tipo 2.

DOI: http://dx.doi.org/10.1590/1982-0194201400006
Corresponding author

Heloisa Carvalho Torres

Alfredo Balena Avenue, 190, Santa Iphigenia, Belo Horizonte, MG, Brazil.

Zip Code: 30100-100

heloisa.ufmg@gmail.com
${ }^{1}$ Escola de Enfermagem, Universidade Federal de Minas Gerais, Belo Horizonte, MG, Brazil. Conflict of interest: no conflicts of interest to declare. 


\section{Introduction}

The increase in life expectancy of the population, combined with a poor diet and a sedentary lifestyle, are contributing to higher rates of occurrence of type 2 diabetes mellitus worldwide. ${ }^{(1)}$ Brazil has approximately six million people with diabetes, and it is estimated that by 2025 this figure will reach 10 million. ${ }^{(1)}$ The care of patients with diabetes involves different strategies, such as multidisciplinary consultations, drug therapy, adoption of healthy habits and participation in educational groups.

Thus, it is necessary to develop educational programs about the adoption of self-care practices. For various reasons, including difficulty of mobility, there is frequently poor adherence to these activities. In these cases, home visits have emerged as an educational health care strategy. ${ }^{(2,3)}$

Home care values the exchange of experiences and knowledge, increasing the bond between patient and health care professional, and the development of orientations based on understanding of the life context. ${ }^{(3,4)}$ This comprehensive and humanized approach to care seeks to improve knowledge of the pathology, bringing patients closer to their treatment, and making them autonomous and responsible for their health. ${ }^{(5-9)}$

During the home visit, patients' understanding and involvement with their care can be facilitated through use of the Conversation Map, a playful instrument created by the International Diabetes Federation to address issues related to the disease through dialogue and exchange of experiences and knowledge. ${ }^{(10)}$

The home visit strategy permits bringing health care education to patients with difficult access to basic health care services. It is a tool that should be studied and worked with in order to increase its viability for health care services.

The objective of this study is to understand the home visit as an educational health care strategy to orient patients with type 2 diabetes on self-care practices.

\section{Methods}

This was a qualitative study conducted in four Basic Health Care Units with a diabetes education pro- gram, in the city of Belo Horizonte, state of Minas Gerais, southeastern Brazil. The study population was composed of patients who did not attend the program. A total of 25 home visits were conducted, scheduled according to the patients' availability.

Data collection occurred during the home visits. The Conversation Map was used to direct the educational actions, which features sections with images and graphics on different subjects. The first section is about feelings towards diabetes mellitus. The second section refers to its pathophysiology, presenting the mechanisms of action of insulin in a playful manner. The third deals with the acute and chronic complications of uncontrolled diabetes mellitus; and the fourth section presents an illustration of the triad of self-care: healthy diet, physical exercise and proper use of medication. In this sense, different themes on the importance of self-care were presented, and doubts were clarified.

A semi-structured interview to discuss the Conversation Map was developed, with guiding questions that explored the knowledge, feelings and lifestyle habits in relation to diabetes mellitus and selfcare. Each visit lasted on average forty-five minutes. The course of the visits was registered manually and through recordings, and these materials were systematized and categorized to make a database, considering recurrent, dissenting and consensual opinions. In the continuation, data were processed and interpreted, based on the content analysis as per the version adapted by Bardin. ${ }^{(11)}$

The development of the study complied with national and international ethical standards for research involving human beings.

\section{Results}

A total of 25 users were visited, including 18 women and seven men, with a mean age of 63.7 years for both sexes. With regard to sociodemographic data, $64 \%$ lived with a partner, and 68\% were professionally inactive. The mean duration of the disease was 15 years for men and 7.7 for women. 52\% of the patients had completed elementary school or less, and $28 \%$ were illiterate. 
Four thematic categories emerged: feelings; knowledge about the disease; adherence to meal plan and physical activity; and barriers to selfcare (Figure 1).

\section{Feelings}

This first category discusses the feelings that arose when the patients discovered that they had the disease, and what was their reaction to this first contact. The first topic of this category was fear of the diagnosis, of having to cope with a chronic illness and take medication for the rest of their life. The second topic was the feeling of anger at the diagnosis and the need to change lifestyle habits. The third topic deals with the feeling of recognition of the need for lifestyle change, and all of the difficulty that this implies for patients with diabetes mellitus. The fourth topic addresses acceptance of the diagnosis and the willingness of patients to take care of themselves.

In this context, the diversity of feelings related to the diagnosis of diabetes mellitus is clear. Accepting the new health condition, negative reactions such as fear and anger, and the need for change are feelings that should be listened to and worked by health care professionals, who must intervene in their doubts and anxieties in order to reassure them about their fears and apprehension.

\section{Knowledge of the pathophysiology of dia- betes mellitus}

From the images on the Conversation Map, some patients demonstrated knowledge about the disease, whereas others managed to make only a few associations. The first topic was extracted: insulin production and metabolism of the disease, explaining the functioning of the human body and its relationship with diabetes. The second topic discusses the complications from diabetes, and most of the patients' knowledge was related to experiences acquired over the years, the most cited being hyper and hypoglycemia, retinopathies, nephropathies and vasculopathies.

This showed that it is important for health care professionals to better orient and explain about the functioning of the disease, as this increases the interaction of patients with their treatment, from the moment they know what is occurring in their body.

\section{Meal plan and physical activity}

The topic meal plan demonstrates the knowledge of the patient regarding the diet, the need for splitting up meals, and the difficulty of changing lifestyles. The patients showed understanding of the need for physical activity in the treatment of diabetes, but a low adherence to this lifestyle, for different reasons.
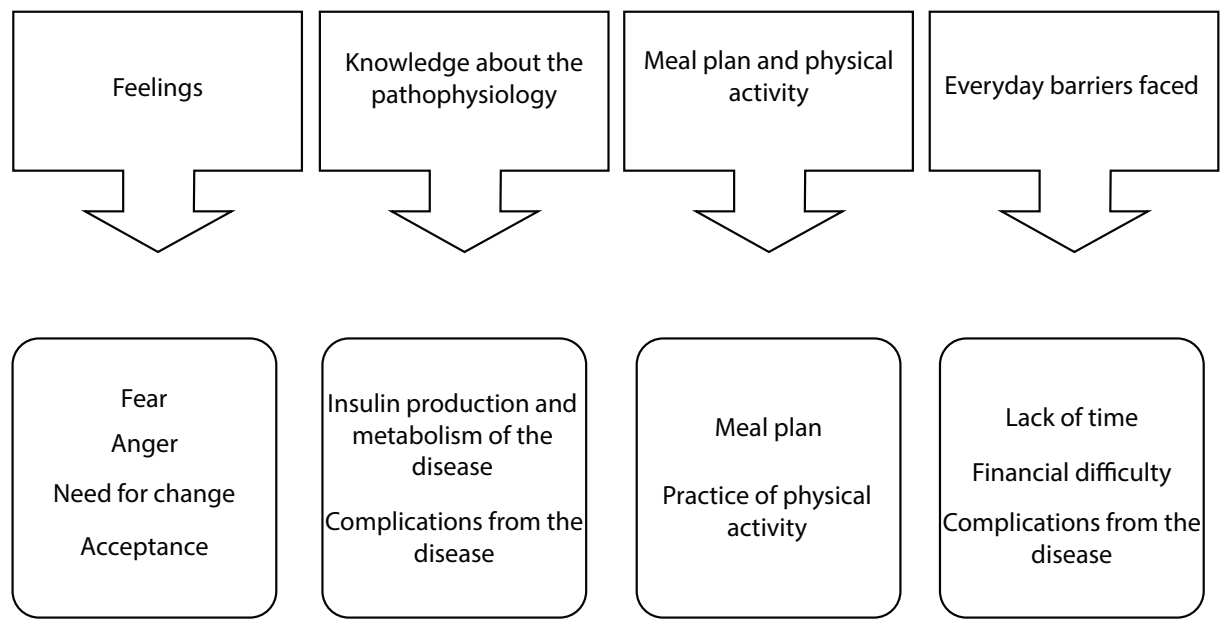

Figure 1. Thematic categories of the study 


\section{Barriers to self-care}

The first topic highlights the lack of time to perform self-care activities such as physical activity or food preparation. The second topic raises the lack of financial resources as a barrier to adhering to a healthy diet or physical activity practices. The third topic deals with complications from diabetes or associated diseases as barriers to the realization of self-care.

Creating strategies for overcoming the barriers found should be an activity developed together by patients and health care professionals, based on each patient's experiences and the context in which they live.

\section{Discussion}

The strategy of home visits allowed guidance for the practice of self-care. The Conversation Map was a facilitating instrument that enabled integration of the concepts and relationships of diabetes mellitus in a playful manner, emphasizing the importance of pathophysiological knowledge for these individuals. (12,13) Another study conducted to evaluate the Conversation Map method pointed to the ease of dialogue and interaction of the subjects from building relationships and sharing experiences, concluding that the tool contributes to self-care. ${ }^{(10)}$

Two data became relevant to this study: age and level of education of the participants. The sample was characterized by an elderly population with a low level of education. The study participants' difficulty to understand the orientations was noticeable. Studies claim that advanced age and low level of education can limit access to information, since there is less understanding of patients as for the orientations given by health care professionals. Thus, adherence to treatment becomes more difficult, which damages self-management of care and therefore control of the disease. ${ }^{(12)}$ This requires health care professionals to have knowledge of the patients, and skills to tailor the language so that it becomes understandable to them, as well as innovative attitudes, such as using the Conversation Map.

The initial feeling after diagnosis of diabetes mellitus was often negative, and at home the feel- ings emerged, and the privacy of the home allowed for broadening the dialogue, which often does not occur during individual consultations in primary health care units. Feelings of denial, sadness and dissatisfaction were the most constant, and always related to the difficulty of adjusting to the new routine established by the disease.

One study that addresses the difficulties reported by diabetics in a support group discusses these feelings, and reports that the statements show different reactions to the diagnosis. ${ }^{(14)}$ Among the negative emotional reactions predominate feelings such as anger and sadness, leading to reactions that include challenges and depression. It was perceived that these emotional factors are intimately connected to family support, knowledge of the disease, and the presence of psychological comorbidities such as depression and anxiety.

Moreover, the need for change in lifestyle often creates dissatisfaction and resistance, leading to denial of the disease. ${ }^{(15)}$ Another study revealed that the way patients react towards diabetes mellitus interferes directly and indirectly in their practice of self-care, and nurses must mediate the conflict between patients' emotions and self-care actions. ${ }^{(16)}$ Thus, educational activities should be supportive and construct knowledge, not only transfer information.

Regarding the pathophysiology of diabetes, participants had some information, but no domain of concepts and relationships between these and self-care. One study found similar results to this study, stating that the majority of patients reported only that "diabetes is sugar in the blood."(2)

It is known that the lack of knowledge about the disease impedes adequate control. Therefore it is necessary that health care education clearly addresses, in accordance with the reality of each patient, what characterizes the disease and what are its consequences. One study that evaluated the patients' knowledge on diabetes mellitus indicated that it significantly improved after the educational intervention. ${ }^{(8)}$

Knowledge about the disease is the basis for achieving correct practice of self-care, as well as 
more effective participation in treatment, but the acquisition of knowledge does not necessarily lead to behavior change. ${ }^{(17-20)}$ This points to the home visit not only as a strategy for the transmission of knowledge, but development of the process of selfcare, and reflection of the importance of adherence to treatment.

With regard to complications, fear was a feeling associated with the possibility of their emergence. Despite fear being a negative feeling, it can stimulate self-care as a way to prevent the onset of these complications. ${ }^{(18)}$ Discussing these aspects, the need was perceived for patients to learn more about diabetes mellitus, and recognition by professionals of the lack of orientation given through the conventional process of selfcare education.

The approach to eating generated a lot of doubt on the part of the patients. It was noticed that the issue is a major concern of treatment and questions were inevitable.

Diabetics commonly have questions on important items of diet therapy, and nutritional orientation by a nutritionist is very important. ${ }^{(12)}$

Given the limitations that patients experience in their daily lives during the long disease process of diabetes, reactions of anger and non-adherence with the meal plan recommended by professionals appear. $^{(18)}$

In addressing the regular practice of physical activity, great resistance was observed among patients. Many reasons are pointed to, such as the lack of time and space for practice, pain from comorbidities and lack of company, among others. Another study found similar data, in which $62 \%$ of patients with diabetes reported not practicing regular physical activity, the main reasons being "lack of time," "discomfort" and "medical condition." (20)

In the home visits, not one of the patients reported regular physical exercise and adherence to the recommended diet, indicating that complete adherence to treatment is still difficult to attain. One study showed that treatments that require decisions or judgments on the part of patients are associated with non-adherence. ${ }^{(20)}$ In addition, per- sonal beliefs about eating, especially in relation to the existence of hazardous or prohibited foods, are hard to change and can interfere with adherence to self-care.

Considering all of these challenges, the role of the health care professional is very important. (18) Professionals should seek interaction with individual patients in order to foster dialogue capable of generating critical thinking about behavior change, according to their sociocultural context. The individual care provided by home visits allows health care professionals to provide specific orientation for each patient, according to their needs, while respecting and valuing their singularities. ${ }^{(7)}$ In addition, providing autonomy to these individuals is more important than knowledge transfer, as it creates space for them to build their own perspectives. ${ }^{(11,15)}$

The difficulties for carrying out home visits are: difficult access due to demographic location, the absence of patients, housework of housewives and the presence of many family members in the household, which hinders interaction between the patient and health care professional. Difficulties related to individuals may also be cited: low degree of cognition, low education, the shaken emotional state of the individual due to personal problems, and non-acceptance of the disease.

As observed, structured home visits consider the individuals' needs, encouraging adherence to treatment through self-care practices, thereby increasing autonomy. Furthermore, home visits promote the approach by health care professionals to the reality of their patients.

\section{Conclusion}

Home visits are an important strategy for health care education to provide guidance on self-care practices to patients with type 2 diabetes mellitus.

\section{Acknowledgements}

This research was conducted with support from the Research Support Foundation of Minas Gerais (FAPEMIG), process APQ-01056-10. The project 
was also supported by BRIDGES (International Diabetes Federation, with an educational grant from Lilly Diabetes).

\section{Collaborations}

Torres HC contributed to the project design, execution of the research and writing of the article. Santos LM collaborated with the relevant critical review of its intellectual content and final approval of the version to be published. Cordeiro PMCS participated in the execution of the research and writing of the article.

\section{References}

1. Albuquerque $A B$, Bosi ML. Visita domiciliar no âmbito da Estratégia Saúde da Família: percepções de usuários no Município de Fortaleza, Ceará, Brasil. Cad Saúde Pública. 2009;25(5):1103-12.

2. Torres HC, Souza ER, Lima MH, Bodstain RC. Intervenção visando os conhecimentos, atitudes e práticas educativas do autocuidado em diabetes mellitus. Acta Paul Enferm. 2011;24(4):67-75.

3. Torres HC, Abreu CR, Nunes CS. Visita domiciliar: estratégia educativa para 0 autocuidado de clientes diabéticos na atenção básica. Rev Enferm UERJ. 2011;19(1):89-93.

4. Teixeira CP. Visita domiciliar: um instrumento de intervenção. Soc Debate. 2009;15(1):165-78.

5. Lopes WO, Saupe R, Massaroli A. Visita domiciliar: tecnologia para 0 cuidado, o ensino e a pesquisa. Ciênc Cuidado Saúde. 2008;7(2):241-7.

6. Otero LM, Zanetti ML, Ogrizio MD. Conhecimento do paciente diabético acerca de sua doença, antes e depois da implementação de um programa de educação em diabetes. Rev Latinoam Enferm. 2008;16(2):231-7.

7. Medeiros PA, Pivetta HM, Mayer MS. Contribuições da visita domiciliar na formação em Fisioterapia. Trabalho Educ Saúde. 2013;10(3):407-26.
8. Peres EM, Dal Poz MR, Grande NR. Visita domiciliar: espaço privilegiado para diálogo e produção de saberes. Rev Enferm UERJ. 2008;14(2):208-13.

9. Kebian LAV, Pena DA, Ferreira VA, Tavares MF, Acioli S. As práticas de saúde enfermeiros na visita domiciliar e a promoção da saúde. Rev APS. 2012;15(1):92-100.

10. Fernandes OD, Worley AV, Beaton SJ, Glasrud P. Educator experience with the U.S. Diabetes Conversation Map $®$ Education Program in the Journey for Control of Diabetes: The IDEA Study. Diabetes Spectrum. 2010;23(3):194-8.

11. Bardin L. Análise de conteúdo. 7a ed. São Paulo; 2011.

12. Torres HC, Pereira FR, Alexandre LR. Avaliação das ações educativas na promoção do autogerenciamento dos cuidados em diabetes mellitus tipo 2. Rev Escola Enferm USP. 2011;45(5):107782.

13. Fontinele RS, Peres LC, Nascimento MA, Boni MS. Avaliação do conhecimento sobre alimentação entre pacientes com diabetes tipo 2. Comun Ciênc Saúde. 2007;18(3):197-206.

14. Freire P. Pedagogia da autonomia: saberes necessários à prática educativa. 24a ed. São Paulo; 2002.

15. Xavier AT, Bittar DB, Ataíde MB. Crenças no autocuidado em diabetes: implicações para a prática. Texto \& Contexto Enferm. 2009;18(1):12430.

16. Sakata KN, Almeida MC, Alvarenga AM, Craco PF, Pereira MJ. Concepções da equipe de saúde da família sobre as visitas domiciliares. Rev Bras Enferm. 2007;60(6):659-64.

17. Trento M, Passera P, Tomalino M, Bajardi M, Pomero F, Allione A, et al. Group Visits Improve Metabolic Control in Type 2 Diabetes . Diabetes Care. 2001;24(6):995-1000.

18. Oliveira NF, Souza MC, Zanetti ML, Santos MA. Diabetes mellitus: desafios relacionados ao autocuidado abordados em Grupo de Apoio Psicológico. Rev Bras Enferm. 2011;64(2):301-37.

19. Filho CV, Rodrigues WH, Santos RB. Papéis de autocuidado subsídios para enfermagem diante das reações emocionais dos portadores de diabetes mellitus. Esc Anna Nery Rev Enferm. 2008;12(1):125-129.

20. Villas Boas LC, Foss MC, Freitas MC, Torres HC, Monteiro LZ, et al. Adesão à dieta e ao exercício físico das pessoas com diabetes mellitus. Texto \& Contexto Enferm. 2011;20(2):272-9. 